\title{
Ecotypes in south-central Spain rivers: the interactions among land use and pollution
}

\author{
C. Llácer, J. L. Moreno \& J. de las Heras \\ Centro Regional de Estudios del Agua, \\ Universidad de Castilla-La Mancha, España
}

\begin{abstract}
A previous physiographical river typology was carried out in south-central Spain by applying System B of the Water Framework Directive (2000/60/CE). The classification distinguished four main river ecotypes: calcareous headwaters, siliceous rivers, plain rivers and large rivers. Physico-chemical water quality was assessed during period 2001-2003 to determinate natural hydrochemical composition and the relationship between land uses and pollutants, mainly nutrients. The river ecotypes corresponded to distinct hydrochemical types. Relatively unpolluted sites between river ecotypes showed no differences in turbidity, DQO, TOC, dissolved oxygen, nitrate, nitrite and phosphate. However, differences in EC, TSS and ammonium concentration between ecotypes were recorded. Correlation and regression analyses showed a strong relationship among land uses and nutrient concentration. Additionally, nitrate concentrations increased significantly when a higher percentage of land was dedicated to agriculture and less to forest. Adequate fertilizer management to avoid high surpluses, and therefore increase depuration efficiency by sewage treatment plant are absolutely necessary measures to reach the environmental objectives set by the Water Framework Directive.
\end{abstract}

Keywords: stream ecotypes, water quality, nutrients, agriculture, Water Framework Directive, Castilla-La Mancha, Spain.

\section{Introduction}

Freshwater ecosystems are greatly influenced by the characteristics of catchment area, as geology, geomorphology and climate. Although, human activities carried out in river catchments can be the most important modifier of the natural chemical composition of freshwater [1,2]. Agricultural activities, urban sewage 
and industrial waste have been identified as the most important sources of pollution in Mediterranean countries [3-8].

Agricultural activities potentially result in multiple impacts to nearby streams: e.g. alteration or loss of riparian vegetation and changes to water chemistry through chemical application to crop. These impacts are considered the main issues for almost every water category regarding pollution in Europe. But, in a great majority of the European countries, nutrient loading by agricultural runoff is the main problem in achieving the environmental objective of Water Framework Directive $(2000 / 60 / C E)$. It is well known that drainage from agricultural land produces large amounts of nitrate and phosphate Hynes [1]. Identification and quantification of those impacts are necessary for an adequate management of land and water resources in river catchments Petts and Calow [9].

The Region of Castilla-La Mancha is dominated by intensive agriculture $(>50 \%$ of the total area) and nitrogen, phosphorus, and potassium-based fertilizers are generously applied to vineyards, cereals and corn crops during the last few decades Domínguez [10]. Until now, in the region, the chemical quality of streams that reflected high concentrations of nutrients has been assessed Moreno et al. [11]. Also, stream water quality has been monitored with elaborate biological indicators based on macrophytes communities Moreno et al. [12, 13] to assess the trophic status. Many studies have established the relationship between land use and pollutants in rivers [14-17]. This relationship is important for integrated, sustainable management and protection of Castilla-La Mancha freshwater resources, particularly in terms of new ecological targets for water quality management under the new directive (WFD).

The aims of this research are: (1) to describe the natural hydrochemical composition for four river ecotypes and (2) to determinate the relationship between land use and pollutants.

\section{Methodology}

\subsection{Study area}

This study was carried out in headwaters and middle reaches of five main Spanish river basins located in south-central Spain corresponding to the limits of the administrative region of Castilla-La Mancha, fig. 1. Climatic conditions correspond to Mediterranean regime, with marked continental conditions. Castilla-La Mancha (CLM) is a region with an extensive area $\left(79.463 \mathrm{~km}^{2}\right.$, $15.7 \%$ of Spain) and very low population density $\left(22.8\right.$ inhabitants $\left.\mathrm{km}^{-2}\right)$ respect to the national averages ( 71 inhabitants $\mathrm{km}^{-2}$ ). Agriculture constitutes the $53 \%$ of land use in Castilla-La Mancha, whereas in Spain it occupies only $37 \%$ of the national surface. As for lithology, we can distinguish the western zone dominated by quartzite, slate and granite (siliceous rocks), and the eastern areas formed by limestone, dolomite, sandstone and conglomerates (calcareous rocks). Sedimentary fills are located in the central area ("La Mancha" Plateau) and the main river valleys which are filled of Tertiary detritic sediments, marls, and gypsum. 
An abiotic stream classification based on the most statistically significant non-human influenced environmental characteristics was used to subdivide the region into relatively homogeneous environmental zones Moreno et al. [11]. Thus, four river ecotypes were established: Calcareous Headwaters (CALH), Siliceous Rivers (SILRIV), Plain Rivers (PLRIV) and Large Rivers (LARIV). CALH and SILRIV include mainly headwaters whereas PLRIV and LARIV include middle and low reaches.

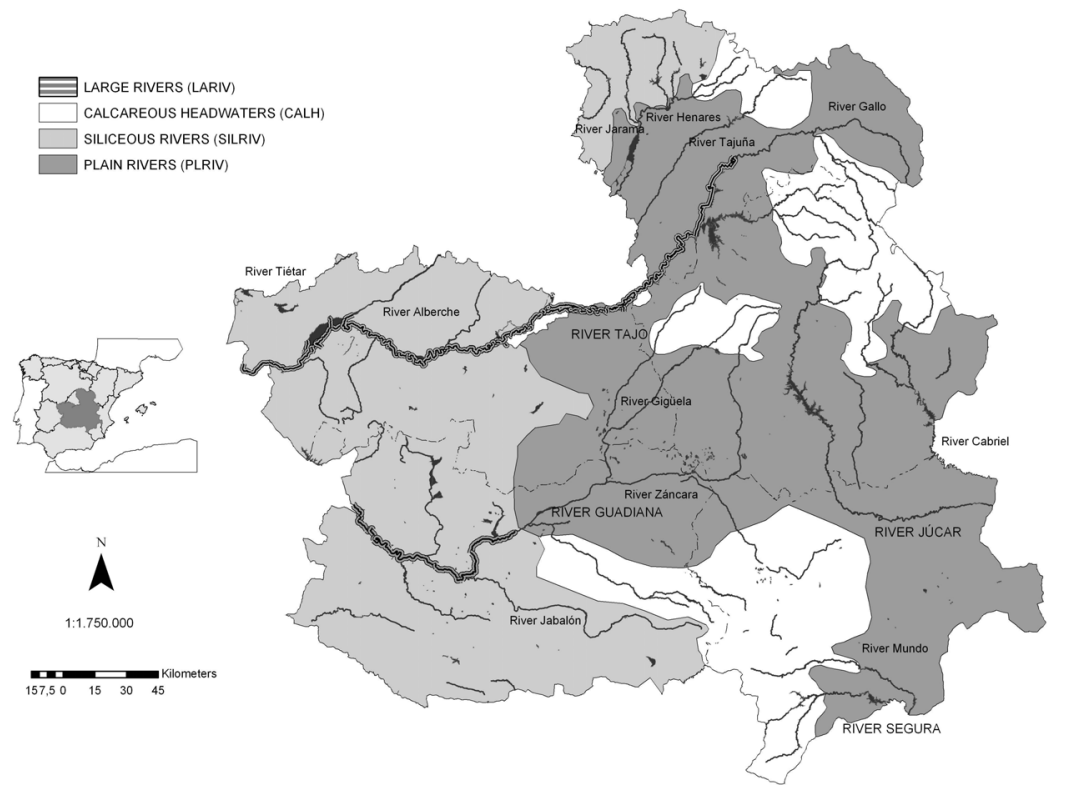

Figure 1: Study area showing main south-central Spanish rivers and boundaries of river ecotypes Moreno et al. [11].

\subsection{Physico-chemical and land use}

A total of 152 sites were selected in order to construct the basic monitoring network in the Castilla-La Mancha. Sites were visited once, twice or three times during period 2001-2003, with winter being the season with the least amount of available data. Electric conductivity, $\mathrm{pH}$ and dissolved oxygen were measured in situ using adequate sensors (Multiline P4 WTW). Water samples were collected in polyethylene bottles $(500 \mathrm{ml})$ and were kept in the refrigerator $\left(4^{\circ} \mathrm{C}\right)$ until the water was analysed. The concentration of nutrients $\left(\mathrm{NO}_{3}^{-}, \mathrm{NO}_{2}^{-}, \mathrm{NH}_{4}^{+}, \mathrm{PO}_{4}^{-3}\right)$ was determined photometrically with MERCK kits (Spectroquant ${ }^{\mathbb{B}}$ ). Total suspended sediments (TSS), chemical oxygen demand (COD), total organic carbon (TOC), turbidity and major ions $\left(\mathrm{HCO}_{3}^{-}, \mathrm{Cl}^{-}, \mathrm{SO}_{4}^{-2}, \mathrm{Ca}^{+2}, \mathrm{Mg}^{+2}, \mathrm{~K}^{+}, \mathrm{Na}^{+}\right)$ were obtained using standard procedures in the laboratory APHA [18].

Land use data were obtained by means of Geographical Information System (GIS) software (ESRI ${ }^{\circledR} \operatorname{ArcMap}^{\mathrm{TM}}$ 8.2). Land uses were summarized into three 
categories from Corine Land Cover 1:100.000 (CLC 1990): agriculture, urban and forest.

\subsection{Statistical analyses}

The SPSS ver.11.5 (SPSS Inc., 2002) statistical software was used for statistical descriptors, analysis of variance and correlations. Non-parametric statistical procedures were applied when normality of residuals and homogeneity of variances did not match with parametric criteria. Simple regression was carried out using Statgraphics Plus v5.1. and data were transformed using $\log _{10}$ and percentage data with $\sqrt{\text { arcsine }}$ to achieve normality assumptions and homocedasticity. Scatter Plots show transformed data.

\section{Results}

\subsection{Physico-chemical water quality}

In this case, relatively unpolluted streams were selected to determinate the water quality in natural conditions within the five river ecotypes. Selected criteria for unpolluted rivers corresponded to those established thresholds for Mediterranean Spanish rivers, $\mathrm{N}-\mathrm{NH}_{4}{ }^{+}<0.5 \mathrm{mg} \mathrm{l}^{-1}$ and $\mathrm{P}_{-} \mathrm{PO}_{4}{ }^{-3}<0.05 \mathrm{mg} \mathrm{l}^{-1}$ Bonada et al. [19]. Then, the river ecotypes showed distinct rock type were investigated the natural hydrochemical characteristics by comparing their ion composition and ion concentration. Calcareous rocks were dominant in CALH, siliceous rocks in SILRIV and detritic rocks in sedimentary valleys (PLRIV and LARIV). Major ions defined two main ion water types: calcium-bicarbonate and calciumsulphate, fig. 2. CALH and SILRIV ecotypes include mainly headwaters and they were calcium-bicarbonate. Calcareous rivers showed higher significant concentration of major ions (bicarbonate, sulphate, calcium and magnesium) than siliceous rivers, showing the lower dissolution rates. LARIV and PLRIV were calcium-sulphate type, they showed a high similarity in ion composition but a high significant difference in sulphate concentration with respect to the other two ecotypes $\left(\mathrm{H}_{3,41}=24.33, \mathrm{p}<0.001\right)$. Large and plain rivers were located mainly on sedimentary detritic rocks and therefore they shared many physicochemical features.

Mean values of pollutants for river ecotypes corresponding to relatively unpolluted streams, are shown in table 1. The analysis of variance between ecotypes only showed significant differences in electric conductivity, total suspended solids and ammonium concentration. The ecotype CALH presented a high nitrate concentration in natural conditions. The ecotype SILRIV showed the lowest electric conductivity and the highest large rivers (LARIV). The result of Tukey test did not fond differences in conductivity values between CALH and PLRIV, whereas significant differences in conductivity were found between SILRIV and LARIV, table 1 . The concentration of ammonium in calcareous and siliceous rivers was lower than plain and large rivers showing differences between upland and lowland rivers. The LARIV ecotype presented the highest value of total suspend solid. Significant differences were observed between 
headwater and middle reaches (CALH and SILRIV) but there were no differences in suspend solid with plain rivers (PLRIV). Large Rivers and Plain Rivers could be considered the same water condition respect to pollutant indicators because no differences were found between pollutant parameters.
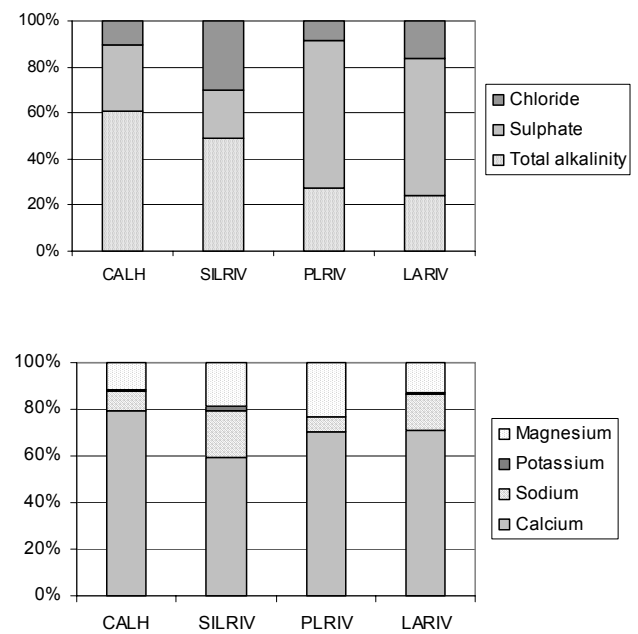

Figure 2: $\quad$ Major ion composition for the four river ecotypes.

Table 1: Mean values and standard deviation of some parameters of unpolluted sites for river ecotypes. Analyses of variance: asterisk indicates significance level $(* \mathrm{p}<0.05 ; * * \mathrm{p}<0.01 ; * * * \mathrm{p}<0.001)$ and letters mean group forms of the Tukey test $(\mathrm{p}<0.05)$.

\begin{tabular}{|c|c|c|c|c|c|c|c|c|c|c|c|c|c|}
\hline & & & & & & & & & & & & & \\
\hline & & Cal & careous Headwc & aters & & Siliceous Rive & & & Plain Rivers & & & Large Rivers & \\
\hline parameter & units & $\mathrm{n}$ & Mean \pm SD & & $\mathrm{n}$ & Mean \pm SD & & $\mathrm{n}$ & Mean \pm SD & & $\mathrm{n}$ & Mean \pm SD & \\
\hline Nitrate & $\mathrm{mgN}-\mathrm{NO}_{3}^{-} \mathrm{l}^{-1}$ & 31 & $3.208 \pm 3.877$ & & 8 & $0.938 \pm 0.800$ & & 17 & $1.502 \pm 1.251$ & & 10 & $0.903 \pm 0.422$ & \\
\hline Nitrite & $\mathrm{mgN}-\mathrm{NO}_{2}^{-1} \mathrm{l}^{-1}$ & 31 & $0.008 \pm 0.006$ & & 8 & $0.006 \pm 0.005$ & & 17 & $0.011 \pm 0.007$ & & 10 & $0.014 \pm 0.009$ & \\
\hline Ammonium $^{* *}$ & $\mathrm{mgN} \mathrm{NH}_{4}^{+} \mathrm{l}^{-1}$ & 31 & $0.046 \pm 0.049$ & $\mathrm{a}$ & 8 & $0.019 \pm 0.018$ & $\mathrm{a}$ & 17 & $0.082 \pm 0.007$ & b & 10 & $0.090 \pm 0.078$ & b \\
\hline Phosphate & $\mathrm{mgP}-\mathrm{PO}_{4}^{-3} \mathrm{l}^{-1}$ & 31 & $0.019 \pm 0.018$ & & 8 & $0.031 \pm 0.014$ & & 17 & $0.022 \pm 0.016$ & & 10 & $0.025 \pm 0.012$ & \\
\hline Conductivity $_{25^{\circ}}$ & $\mu \mathrm{Scm}^{-1}$ & 28 & $666.6 \pm 191.9$ & $\mathrm{a}$ & 8 & $148.0 \pm 150.5$ & $\mathrm{~b}$ & 15 & $843.1 \pm 413.0$ & $\mathrm{a}$ & 10 & $1029.9 \pm 532.3$ & $\mathrm{c}$ \\
\hline COD & $\mathrm{mgl}^{-1}$ & 14 & $38.6 \pm 34.7$ & & 5 & $21.0 \pm 8.4$ & & 10 & $48.0 \pm 27.8$ & & 5 & $39.6 \pm 20.3$ & \\
\hline Dissolved oxygen & $m g 1^{-1}$ & 24 & $9.4 \pm 1.6$ & & 8 & $9.2 \pm 0.9$ & & 14 & $9.8 \pm 1.9$ & & 10 & $8.0 \pm 1.7$ & \\
\hline $\mathrm{TSS}^{*}$ & $\mathrm{mgl}^{-1}$ & 27 & $5.4 \pm 8.5$ & $\mathrm{a}$ & 8 & $4.9 \pm 6.2$ & $\mathrm{a}$ & 14 & $7.2 \pm 8.0$ & $a b$ & 9 & $17.2 \pm 18.9$ & b \\
\hline TOC & $m g l^{-1}$ & 21 & $1.7 \pm 1.0$ & & 7 & $2.9 \pm 1.7$ & & 12 & $1.5 \pm 0.4$ & & 6 & $2.3 \pm 2.2$ & \\
\hline Turbidity & U.N.F. & 27 & $1.2 \pm 1.6$ & & 8 & $28.6 \pm 77.0$ & & 14 & $2.4 \pm 2.6$ & & 10 & $6.8 \pm 14.4$ & \\
\hline
\end{tabular}

\subsection{Land use and pollutants}

All sites, polluted and unpolluted, were taken into account to investigate the relationships between land uses and pollution. The correlation analysis (Spearman) indicated that land uses were associated with certain pollutants, 
mainly nutrient concentrations. Significant correlations between land use and pollutant parameters, are shown in table 2. For the total study area (CLM), significant positive correlations were found between the percentage of urban area and nitrite, ammonium and phosphate levels. Agriculture was correlated with nitrogen forms and forested land showed a negative correlation with nitrate and phosphate concentrations. In all river ecotypes, agricultural use was correlated with nitrate and nitrite, whereas forest use presented negative correlation with nitrate concentration. The highest correlation coefficient was recorded in calcareous headwaters for nitrate and agriculture $(\mathrm{r}=0.637, \mathrm{p}<0.001)$. Urban use was correlated to some nutrient in all ecotypes except for calcareous headwaters, where no correlation was found with nutrients. Phosphate and nitrate were positively correlated to urban use only in case of large rivers.

Table 2: Spearman coefficients between land use types and pollutant parameters.

\begin{tabular}{|c|c|c|c|c|c|c|c|c|c|c|c|c|c|c|c|c|}
\hline & & \multicolumn{3}{|c|}{ CALH } & \multicolumn{3}{|c|}{ SILRIV } & \multicolumn{3}{|c|}{ PLRIV } & \multicolumn{3}{|c|}{ LARIV } & \multicolumn{3}{|c|}{ CLM } \\
\hline & & $\mathrm{n}$ & $\mathrm{r}$ & $\mathrm{p}$ & $\mathrm{n}$ & $\mathrm{r}$ & $\mathrm{p}$ & $\mathrm{n}$ & $r$ & $\mathrm{p}$ & $\mathrm{n}$ & $\mathrm{r}$ & $\mathrm{p}$ & $\mathrm{n}$ & $\mathrm{r}$ & $\mathrm{p}$ \\
\hline \multirow[t]{8}{*}{ Urban } & $\mathrm{NH}_{4}^{+}$ & & ns & & & ns & & 59 & 0.272 & $*$ & 26 & 0.429 & $*$ & 196 & 0.306 & $* * *$ \\
\hline & $\mathrm{NO}_{3}^{-}$ & & $\mathrm{ns}$ & & & $\mathrm{ns}$ & & & ns & & 28 & 0.378 & $*$ & & ns & \\
\hline & $\mathrm{NO}_{2}^{-}$ & & ns & & 47 & 0.289 & * & 64 & 0.298 & $*$ & & ns & & 207 & 0.384 & $* * *$ \\
\hline & $\mathrm{PO}_{4}{ }^{3-}$ & & ns & & & $\mathrm{ns}$ & & & ns & & 25 & 0.400 & $*$ & 185 & 0.224 & $* *$ \\
\hline & TOC & & ns & & 28 & 0.586 & $*$ & 38 & 0.452 & $* *$ & 16 & 0.758 & $* *$ & 142 & 0.421 & $* * *$ \\
\hline & COD & 41 & 0.346 & $*$ & & ns & & & ns & & & ns & & & ns & \\
\hline & TSS & 72 & 0.242 & $*$ & & $\mathrm{~ns}$ & & & $\mathrm{~ns}$ & & & $\mathrm{~ns}$ & & & ns & \\
\hline & Turbidity & 73 & 0.345 & $* *$ & 32 & 0.364 & $*$ & & ns & & & $\mathrm{ns}$ & & 171 & 0.302 & $* *$ \\
\hline \multirow[t]{8}{*}{ Agriculture } & $\mathrm{NH}_{4}^{+}$ & & $\mathrm{ns}$ & & 41 & 0.351 & * & & ns & & & $\mathrm{ns}$ & & 196 & 0.207 & $* *$ \\
\hline & $\mathrm{NO}_{3}^{-}$ & 80 & 0.637 & $* * *$ & 47 & 0.395 & $* *$ & 77 & 0.268 & $*$ & 28 & 0.442 & $*$ & 232 & 0.235 & $* * *$ \\
\hline & $\mathrm{NO}_{2}^{-}$ & 68 & 0.474 & $* * *$ & 47 & 0.566 & $* * *$ & 64 & 0.404 & $* *$ & 28 & 0.540 & $* *$ & 207 & 0.449 & $* * *$ \\
\hline & $\mathrm{PO}_{4}{ }^{3-}$ & & ns & & 43 & 0.289 & $*$ & & ns & & 25 & 0.479 & $*$ & & ns & \\
\hline & TOC & & ns & & 28 & 0.419 & $*$ & 38 & 0.405 & $*$ & 16 & 0.763 & $* * *$ & 142 & 0.351 & $* * *$ \\
\hline & COD & & ns & & & $\mathrm{ns}$ & & & ns & & & ns & & & ns & \\
\hline & TSS & & ns & & & $\mathrm{ns}$ & & & $\mathrm{ns}$ & & & ns & & 169 & 0.158 & $*$ \\
\hline & Turbidity & 73 & 0.263 & $*$ & 32 & 0.554 & $* *$ & & $\mathrm{~ns}$ & & & ns & & 171 & 0.260 & $* *$ \\
\hline \multirow[t]{8}{*}{ Forest } & $\mathrm{NH}_{4}^{+}$ & & ns & & & ns & & & $\mathrm{ns}$ & & & ns & & & ns & \\
\hline & $\mathrm{NO}_{3}{ }^{-}$ & 80 & -0.632 & $* * *$ & 47 & -0.328 & $*$ & 77 & -0.268 & $*$ & 28 & -0.506 & $*$ & 232 & -0.227 & ** \\
\hline & $\mathrm{NO}_{2}^{-}$ & 68 & -0.469 & $* * *$ & 47 & -0.599 & $* * *$ & 64 & -0.395 & $* *$ & 28 & -0.547 & $* *$ & & $\mathrm{~ns}$ & \\
\hline & $\mathrm{PO}_{4}^{3-}$ & & ns & & 43 & -0.419 & $* *$ & & ns & & 25 & -0.505 & $*$ & 185 & -0.170 & $*$ \\
\hline & TOC & & ns & & 28 & 0.419 & * & & ns & & & ns & & 142 & 0.192 & $*$ \\
\hline & COD & & ns & & & ns & & & ns & & & ns & & & ns & \\
\hline & TSS & & ns & & & ns & & 45 & -0.367 & $*$ & & ns & & & ns & \\
\hline & Turbidity & & $\mathrm{ns}$ & & & ns & & 45 & -0.387 & $* *$ & & $\mathrm{~ns}$ & & & ns & \\
\hline
\end{tabular}

With respect to other pollution indicators, the correlation and significant were lower than nutrient concentrations, in table 2. Agricultural and urban land use were significantly correlated with TOC in all river ecotypes except calcareous headwaters. On the other hand, the percentage of urban area showed a correlation with COD, TSS and turbidity in the ecotype CALH. Total suspend solid and turbidity presented a negative correlation with forest area only in plain rivers 
(PLRIV). In the case of Castilla-La Mancha, the increase of agricultural and urban land use presented significant correlation with TOC and turbidity.

Table 3: Results of linear regression between land use and nutrient concentrations.

\begin{tabular}{lccc} 
& URBAN & AGRICULTURE & FOREST \\
\hline $\mathrm{NH}_{4}{ }^{+}$ & $\begin{array}{l}\mathrm{R}^{2}=0.55 \\
\mathrm{p}<0.001\end{array}$ & $\begin{array}{l}\mathrm{R}^{2}=0.53 \\
\mathrm{p}<0.001\end{array}$ & $\begin{array}{c}\mathrm{R}^{2}=-0.34 \\
\mathrm{p}<0.001\end{array}$ \\
& & & \\
$\mathrm{NO}_{3}{ }^{-}$ & $\mathrm{R}^{2}=0.34$ & $\mathrm{R}^{2}=0.62$ & $\mathrm{R}^{2}=-0.6$ \\
& $\mathrm{p}<0.001$ & $\mathrm{p}<0.001$ & $\mathrm{p}<0.001$ \\
& & & \\
$\mathrm{NO}_{2}{ }^{-}$ & $\mathrm{R}^{2}=0.48$ & $\mathrm{R}^{2}=0.55$ & $\mathrm{R}^{2}=-0.33$ \\
& $\mathrm{p}<0.001$ & $\mathrm{p}<0.001$ & $\mathrm{p}<0.001$ \\
$\mathrm{PO}_{4}{ }^{3-}$ & $\mathrm{R}=0.6$ & $\mathrm{R}=0.38$ & $\mathrm{R}^{2}=-0.40$ \\
& $\mathrm{p}<0.001$ & $\mathrm{p}<0.001$ & $\mathrm{p}<0.001$ \\
\hline
\end{tabular}
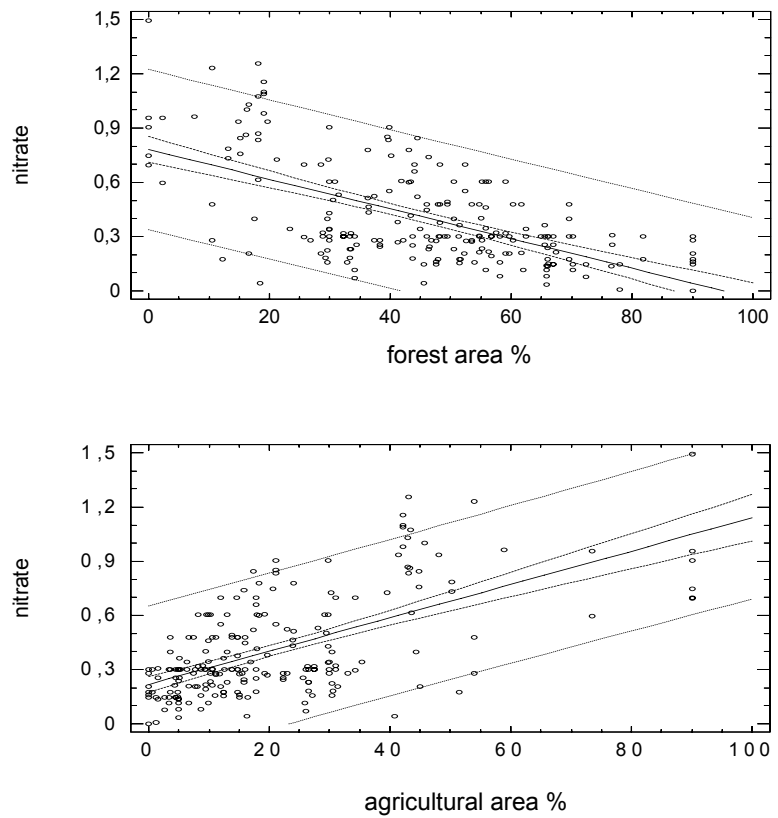

Figure 3: Scatter plots for the concentration of nitrate versus the increase of agricultural and forest percentages. It indicates the regression line, the $95 \%$ confidence interval and the $95 \%$ prediction interval. 
Finally, the regression analyses recorded a strong trend in the percentage of land use type and nutrients levels, in table 3. Concentrations of nitrogen compounds were higher correlated to the increase of land dedicated to agriculture. These results fit in with Spearman correlation for the Region of Castilla-La Mancha, as shown in table 2. For urban use, however, there were significant correlations with phosphate and ammonium levels. A negative significant correlation was obtained between forested area and all nutrients, mainly nitrate concentrations. Figure 3 plots the highest significant correlation values that corresponded to the percentage of agricultural and forested area against nitrate concentrations. Scatter Plots revealed a linear relationship with a positive significant correlation when the percentage of agriculture increases and negative relation with decreasing forested area.

\section{Discussion}

The water quality of streams can be expected to differ between ecoregions in terms of major ions, nutrients, organic matter and silt loading because it is a product of atmospheric inputs, climatic conditions, land use practices, an specially catchment bedrock [20, 21]. However, Harding et al. [22] found little correspondence between stream water chemistry and ecoregions in South Island, New Zealand. In this study, the river ecotypes corresponded to distinct major ion composition and major ion concentration. The calcium-bicarbonate type dominated siliceous and calcareous headwaters (SILRIV and CALH) whereas calcium-sulphate type dominated downstream (PLRIV and LARIV), probably due to the contribution of sulphates by the weathering of sedimentary rocks (Allan [2]). However, Sala [7] concluded that the high sulphates values were a consequence of agriculture as well as industrial and domestic inputs.

The relationships between land use and nutrient concentration in this study produced important conclusions. Urban land use increased phosphorus and nitrogen levels in rivers, agricultural use mainly increased nitrogen compounds, and forested land showed negative correlations with nitrate and phosphate. This negative correlation supports the opinion that forest catchments periodically retain larger amounts of nutrients [23, 24]. In siliceous rivers, agriculture originated ammonium and phosphate pollution due to high densities of livestock ( $>2500$ heads $x$ 1000). At calcareous headwaters (CALH) the highest correlation with nitrate was recorded $(\mathrm{r}=0.632, \mathrm{p}<0.001)$. In this river ecotypes forested land dominates, agricultural land use of territory is bellow $50 \%$, and population is low. Therefore, the absence of large urban areas in calcareous headwaters leads one to attribute the high nitrate values to agricultural activities Bellos et al. [6]. In the case of small upland catchment in Indonesia, it appears to have a larger impact due to diffuse pollution associated with land use than the point source impact Walsh et al. [25]. Plain and large rivers were located in sedimentary valleys and plateaus with the largest catchment areas and the highest percentage of catchment dedicated to agricultural and urban use, therefore indicating that human impact is greatest in these river ecotypes (PLRIV and LARIV). Ammonium was correlated to urban land use only in plain and large 
rivers, thus indicating high population densities. Agricultural use was also correlated to nitrite and nitrate in both river ecotypes receiving high nutrient loading by agricultural run-off, industry and domestic sewages. However, phosphate was correlated to agriculture only in the case of large rivers (LARIV) and siliceous rivers (SILRIV), both river ecotypes showing high livestock densities and high agricultural development.

Study results highlight the close association between land use types and nutrient levels in rivers. As, in other study where anthropogenic land uses primarily defined nutrient baseflow chemistry patterns at regional and watershed levels Dow et al. [17]. Nitrate has shown a strong relationship with land use types because nitrogen compounds are easily oxidised to nitrate and contribute to nitrate leakage into rivers. The increase of nitrate concentrations was better explained by the increase in agricultural percentage $\left(R^{2}=0.384\right)$ and the decrease in forests $\left(\mathrm{R}^{2}=0.367\right)$, fig. 3. These results reflect that the nitrogen fertilization of cropland produce surpluses which are then emitted to water channels. Extensive areas in Castilla-La Mancha have been affected by groundwater pollution caused by nitrates Berzas et al. [26], which also influence nitrate levels in rivers. The European Environment Agency (EEA) found a close relationship between nitrogen load and the surplus of nitrogen applied to agriculture for large European river catchment EEA [27]. On the other hand, the forested area buffers the levels of nutrients providing an effective reduction of nitrate load. The surface runoff of nutrients movement to streams can be reduced by riparian forest Schultz et al. [24]. According to EEA [27], discharge of phosphorus from point sources in Europe has decreased significantly during the past 30 years, mainly due to improved purification of urban wastewater. In this study, phosphate was strong related to urban land use, showing the need of tertiary treatment in the sewage treatment plants to reduce the load of nutrient discharge into rivers.

\section{Conclusions}

Since 1993, crop lands increased 5\% but production has doubled in Castilla-LA Mancha, which means an important increase in nutrient fertilization (Regional Agriculture Database). The use and abuse of nitrogen and phosphorus fertilizers have caused high nutrient loads to flow into Central Spanish rivers, with additional serious pollution produced by urban sewage. Adequate management of fertilizers to avoid high surpluses and therefore increase depuration efficiency by sewage treatment plants are absolutely necessary measures to reach the environmental objectives set by the Water Framework Directive. Our results are of relevance for integrated, sustainable management and protection of CastillaLa Mancha freshwater resources and ecosystems.

\section{References}

[1] Hynes, H.B.N., The Ecology of Running Waters. Liverpool University Press, Liverpool, 1970. 
[2] Allan, J.D., Stream Ecology: Structure and Function of running waters. Kluwer Academic Publishers, Dordrecht.

[3] Prenda, J. \& Gallardo, A., Self-purification, temporal variability and the macroinvertebrates community in small lowland Mediterranean streams receiving crude domestic sewage effluents. Archiv für Hydrobiologie 136, pp.159-270, 1996.

[4] Fytianos, K., Siumka, A., Zachariadis, G.A. \& Beltsios, S., Assessment of the quality characteristics of Pinos River, Greece. Water, Air, and Soil Pollution, 136, pp. 317-329, 2002.

[5] Koukal, B., Dominik, J., Vignati, D., Arpagaus, P. Santiago, S., Ouddane, B. \& Benaabidate, L., Assessment of water quality and toxicity of polluted Rivers Fez and Sebou in the region of Fez (Morocco). Environmental Pollution, 131 (1), pp. 163-172, 2004.

[6] Bellos, D., Sawidis, T. \& Tsekos, I., Nutrient chemistry of River Pinios (Thessalia, Greece). Environment International, 30 (1), pp.105-115, 2004.

[7] Sala, M., Hydrogeomorphological assessment of surface and groundwater quality in the Ridaura stream, Catalan Ranges, NE Iberian Peninsula. Land Degradation and Development, 15 (3), pp. 311-323, 2004.

[8] Dassenakis, M., Scoullos, M., Foufa, E., Krasakopoulou, E., Pavlidou, A. \& Kloukiniotou, M., Effects of multiple source pollution on a small Mediterranean river. Applied Geochemistry, 13 (2), pp. 197-211, 1998.

[9] Petts, G. \& Callow, P., (eds). River restoration. Blackwell Science: Oxford, 1996.

[10] Domínguez, A., Tratado de fertilización. Mundi-Prensa: Madrid, 1997.

[11] Moreno, J.L., Navarro, C. \& De Las Heras, J., Abiotic ecotypes in southcentral Spanish rivers: Reference conditions and pollution, Environmental Pollution, 143, pp. 388-396, 2006.

[12] Moreno, J.L., Navarro, C. \& De Las Heras, J., Propuesta de un índice de vegetación acuática (IVAM) para la evaluación del estado trófico de los ríos de Castilla-La Mancha: Comparación con otros índices bióticos, Limnetica, 25 (3), pp. 821-838, 2006.

[13] Moreno, J.L., Navarro, C. \& De Las Heras, J., Propuesta de un índice de vegetación acuática (IVAM para la evaluación rápida del estado trófico de los ríos de Castilla-La Mancha: comparación con otros índices bióticos, Tecnología del Agua, 143, pp. 388-396, 2006.

[14] Ometo, J.P.H.B., Martinelli, L.A., Ballesteri, M.A., Gessner, A., Krusche, A.V., Victoria, R.L. \& Williams, M., Effects of land use on water chemistry and macroinvertebrates in two streams of the Piracicaba river basin, south-east Brazil. Freshwater Biology, 44, pp. 327-337, 2000.

[15] Donner, S., The impact of cropland cover on river nutrient levels in the Mississippi River Basin, Global Ecology and Biogeography, 12 (4), pp. 341-355, 2003.

[16] Schilling, K.E. \& Spooner, J., Effect of watershed-scale land use change on stream nitrate concentration, Journal of Environmental Quality, 35 (6), pp. 2132-2145, 2006. 
[17] Dow, C.L., Arscott, D.B., Newbold, J.D., Relating major ions and nutrients to watershed conditions across a mixed-use, water-supply watershed, Journal of the North American Benthological Society, 25 (4), pp. 887-911, 2006.

[18] APHA, Standard methods for the examination of water and wastewater. American Public Health Association, Washington D.C., 1989.

[19] Bonada, N, N. Prat, A. Munné, M. Rieradevall, J. Alba-Tercedor, M. Alvarez, J. Avilés, J. Casas, P. Jáimez-Cuéllar, A. Mellado, G. Moya, I. Pardo, S. Robles, G. Ramón, M.L. Suárez, M. Toro, R. Vidal-Abarca, S. Vivas y C. Zamora-Muñoz, Criterios para la selección de condiciones de referencia en los ríos mediterráneos. Resultados del proyecto GUADALMED. Limnetica, 21 (3-4), pp. 99-114, 2002.

[20] Stumm, W. \& Morgan, J.J., Aquatic chemistry. John Wiley and Son, New York, 1981.

[21] Gibbs, R.J., Mechanisms controlling world water chemistry. Science, 170, pp. 1088-1090, 1970.

[22] Harding, J.S., Witerbourn, M.J. \& Wayne, F.M., Stream faunas and ecoregions in South Island, New Zealand: do they correspond? Archiv für Hydrobiologie, 140 (3), pp.289-307, 1997.

[23] May, L., House, W.A., Bowes, M. \& McEvoy, J., Seasonal export of phosphorus from a lowland catchment: upper River Cherwell in Oxfordshire, England Science of Total Environment, 269, pp. 117-130, 2001.

[24] Schultz, R.C., Isenhart, T.M., Simpking, W.W. \& Colletti, J.P., Riparian zones forest buffers in agrosystems- lessons learned from the Bear Creek Watershed, central Iowa, USA Agroforestry Systems, 61 (1), pp. 35-40, 2004

[25] Walsh, C.J., Gooderham, J.P.R., Grace, M.R., Sdraulig, S., Rosyidi, M.I. $\&$ Lelono, A., The relative influence of diffuse- and point-sources disturbances on a small upland stream in East Java, Indonesia: a preliminary investigation Hydrobiologia, 487, pp. 183-192, 2002.

[26] Berzas, J.J., García, L.F., Martín-Álvarez, P.J., \& Rodríguez, R.C., Quality assessment and chemometric evaluation of a fluvio-lacustrine system: Ruidera Pools Natural Park (Spain). Water, Air and Soil Pollution, 155, pp. 269-289, 2004.

[27] EEA, Source apportionment of nitrogen and phosphorus inputs into the aquatic environment, Report No 7/2005. European Environment Agency, Copenhagen, 2005. 